\title{
PENGARUH TRAINING KOGNITIF TERHADAP KEMAMPUAN KOGNITIF PADA LANSIA DI DESA SOBOKERTO KECAMATAN NGEMPLAK BOYOLALI
}

\author{
Prasaja $^{1}$, Maharso Adi Nugroho ${ }^{2}$ \\ ${ }^{1,2}$ Kementerian Kesehatan Politeknik Kesehatan Surakarta Jurusan Okupasi Terapi \\ Diterima : 13 Oktober 2018, Disetujui : 30 Oktober 2018 \\ e-mail : prasajaahmad@gmail.com
}

\begin{abstract}
Background: The elderly phase is the last stage of development over every human life span. The process starts as infant phase followed by children, adults, old and elderly. Thorough out the elderly phase, there are significant decreases of tissue functions, yet it hampers the ability for body to repair any possible body damages. The decreasing functions in the elders, especially the cognitive functions would affect their functional independence in the long run. Method: A quantitative pre-experimental design with type one-group pre test-post test that compared the average scores between pre and post cognitive training, with no any control-group involved. The sampling technique used was purposive. Inclusion criteria were elders above 60 years old with good level of consciousness (place, time, person), and have no severe cognitive problems. The purpose of the research is to identify the effect of cognitive training on cognitive ability of the elders in Sobokerto Village Ngemplak Boyolali subdistrict and also to depict the elders' population demographic based on age, gender and education. Data analysis was done with the use of quantitative analysis of paired sample t-test as the data is normally distributed. Sources of research data are presented in the form of: (1) primary data from examination results by using MMSE instruments, (2) secondary data from archives and documents. The techniques used to collect data were plain tests, observations and document studies. The outcome of the research is cognitive training module used thorough out the intervention programs. Result: this study are: (1) There is a clear evidence of positive result of cognitive training on cognitive ability of the elders $(p=0.001)$, (2) age distribution of elderly in Sobokerto Village Ngemplak subdistrict Boyolali Regency were dominated by age of $<75$ years (66.7\%), (3) the total population of the elders in Sobokerto Village, Ngemplak sub-district, Boyolali regency are (83.3\%), (4) the education level amongst the elders in Sobokerto village, Ngemplak sub-district, Boyolali regency are mostly junior high school (38.9\%). Conclusion : There was a positive influence and significant cognitive training on cognitive abilities of the elderly in the village of Sobokerto Ngemplak Boyolali
\end{abstract}

Keywords : Cognitive training, cognitive ability of the elders, MMSE

\section{PENDAHULUAN}

Proses menua (Aging) adalah proses alami yang disertai adanya penurunan kondisi fisik, psikologis maupun sosial yang saling berinteraksi satu sama lain. Keadaan ini cenderung berpotensi menimbulkan masalah kesehatan secara umum maupun kesehatan jiwa secara khusus pada lansia (Kuntjoro, 2002). 
Kognitif merupakan suatu proses pekerjaan pikiran yang dengannya seseorang menjadi waspada akan objek pikiran atau persepsi, mencakup semua aspek pengamatan, pemikiran dan ingatan (Dorland, 2002). Setiati et al. (2006) menyebutkan adanya perubahan kognitif yang terjadi pada lansia, meliputi berkurangnya kemampuan meningkatkan fungsi intelektual, berkurangnya efisiensi tranmisi saraf di otak (menyebabkan proses informasi melambat dan banyak informasi hilang selama transmisi), berkurangnya kemampuan mengakumulasi informasi baru dan mengambil informasi dari memori, serta kemampuan mengingat kejadian masa lalu lebih baik dibandingkan kemampuan mengingat kejadian yang baru saja terjadi. Penurunan menyeluruh pada fungsi sistem saraf pusat dipercaya sebagai kontributor utama perubahan dalam kemampuan kognitif dan efisiensi dalam pemrosesan informasi (Papalia et al., 2008). Fungsi kognitif seseorang meliputi berbagai fungsi berikut, antara lain: (1) Orientasi, (2) Bahasa, (3) Atensi, (4) Memori, (5) Fungsi konstruksi, (6) Kalkulasi, dan (7) Penalaran. Cognitif Adaptation Training (CAT) adalah salah satu metode training kognitif dengan pendekatan kompensasi yang menggunakan dukungan lingkungan dan petunjuk seperti tanda-tanda, check list, alarm penanda dan pengelompokan serta melakukan urutan rutinitas yang tepat seperti pemberian pengobatan dan perawatan diri di rumah (Velligan et al, 1996). Terapi kompensasi rehabilitasi bertujuan tidak hanya untuk meningkatkan fungsi kognitif dengan mengurangi kesalahan dalam proses belajar tetapi juga untuk meminimalkan hambatan yang timbul pada aktivitas sehari-hari dan menciptakan lingkungan rumah yang mendukung dimana keunggulan terapi kompensasi adalah kurang menimbulkan kebosanan (Green, 2009). CAT menggabungkan latihan strategi kompensasi dengan modifikasi lingkungan, mendorong pasien untuk berinteraksi terhadap lingkungannya. Intervensi dapat berlangsung singkat, murah, praktis dan dapat diterapkan secara menyeluruh pada kehidupan sehari-hari (Velligan et al, 2008). Intervensi ini bertujuan untuk mencapai 4 domain memori, perhatian dan kewaspadaan, pembelajaran dan fungsi eksekutif. Setiap sesi dirancang untuk meninjau pekerjaan dan strategi sebelumnya, kemudian memperkenalkan dan mempraktekkan strategi kompensasi baru serta membantu pasien dalam mengembangkan rencana secara individu untuk menerapkan strategi dalam kehidupan sehari-hari. Setiap minggu diberikan pekerjaan rumah untuk mempromosikan penggunaan strategi di luar training dan memecahkan hambatan yang muncul (Bustillo et al, 2001; Maples et al, 2007).

Penelitian ini bertujuan untuk mengetahui pengaruh training kognitif terhadap kemampuan kognitif lansia di Desa Sobokerto Kecamatan Ngemplak Boyolali, sebelum training dilakukan pemeriksaan fungsi kognitif dengan menggunakan instrument MMSE, kemudian diberi training kognitif terhadap subyek penelitian, dan dilakukan test kembali setelah training serta dianalisis apakah ada pengaruh training kognitif terhadap kemampuan kognitif.

Instrument penelitian mengguna kan Mini Mental Status Examination (MMSE). Kegunaan utama MMSE berubah menjadi suatu media untuk mendeteksi dan mengikuti perkembangan 
gangguan kognitif yang berkaitan dengan kelainan neurodegenerative. MMSE merupakan suatu skala terstruktur yang terdiri dari 30 poin yang dikelompokkan menjadi 7 kategori : orientasi terhadap tempat (negara, provinsi, kota, gedung dan lantai), orientasi terhadap waktu (tahun, musim, bulan, hari dan tanggal), registrasi (mengulang dengan cepat 3 kata), atensi dan konsentrasi (secara berurutan mengurangi 7 , dimulai dari angka 100 , atau mengeja kata DUNIA secara terbalik), mengingat kembali (mengingat kembali 3 kata yang telah diulang sebelumnya), bahasa (memberi nama 2 benda, mengulang kalimat, membaca dengan keras dan memahami suatu kalimat, menulis kalimat dan mengikuti perintah 3 langkah), dan kontruksi visual (menyalin gambar).

Interpretasi MMSE didasarkan pada skor yang diperoleh pada saat pemeriksaan: (a) Skor 24-30 diinterpretasi kan sebagai fungsi kognitif normal, (b) Skor 17-23 berarti probable gangguan kognitif, (c) Skor 0-16 berarti definite gangguan kognitif.

\section{METODE PENELITIAN}

Penelitian ini merupakan penelitian quantitative pre-experimental design tipe one-group pretest-posttest yaitu membandingkan rerata skor antara sebelum training dan setelah training kognitif, tanpa ada kelompok kontrol Kelompok pertama yaitu sebelum mendapat training kognitif. Kelompok kedua yaitu setelah mendapat training kognitif. Populasi penelitian ini semua lansia yang berdomisili di Desa Sobokerto Kecamatan Ngemplak Kabupaten Boyolali. Sampel diambil dengan teknik purposive sampling yang memenuhi kriteria inklusi yaitu lansia berusia lebih dari 60 tahun, tingkat kesadaran cukup baik (tempat, waktu, orang), dan tidak ada gangguan kognitif berat. Kriteria eksklusi: lansia dengan infeksi akut, terminal disease, patah tulang akut, severe circulatatory disease, lansia pada long term care maupun lansia yang hanya beraktifitas di bed. Alat ukur penelitian menggunakan Tes Mini Mental Status Examination (MMSE) untuk mengukur kemampuan kognitif. Uji statistik menggunakan uji komparasi parametrik berpasangan (paired sample $t$ test).

\section{HASIL PENELITIAN \\ Karakteristik Subyek Penelitian}

Penelitian telah dilaksanakan di Lahan Rehabilitasi Bersumberdaya Masyarakat di Desa Sobokerto Kecamatan Ngemplak Kabupaten Boyolali selama 2 bulan menggunakan rancangan quantitative pre-experimental design tipe one-group pretest-posttest tanpa kelompok kontrol, dengan jumlah populasi 52 orang, sampel yang sesuai kriteria inklusi 36 orang, tidak ada yang drop out. Diawali dengan pre test kemampuan kognitif pada Hari Jumat 14 Juli 2017, intervensi setiap Hari Jumat dimulai pada Hari Jumat 21 Juli 2017 sampai Hari Jumat 18 Agustus 2017, dan post test pada Hari Jumat 25 Agustus 2017.

\section{PEMBAHASAN}

Karakteristik subyek penelitian pada penelitian ini meliputi distribusi Umur, Jenis Kelamin dan Tingkat Pendidikan. Deskripsi karakteris tik subyek penelitian tertera pada tabel 1 
Tabel 1. Karakteristik Subyek Penelitian

\begin{tabular}{lccc}
\hline Karakteristik & Rentangan & $\begin{array}{c}\text { Frekuensi } \\
(\mathbf{n = 3 6})\end{array}$ & $\begin{array}{c}\text { Prosentase } \\
(\mathbf{n = 1 0 0 \% )}\end{array}$ \\
\hline Umur & $=<74$ th & 24 & 66.7 \\
& $75-90$ th & 12 & 33.3 \\
& $>90$ th & 0 & 0.0 \\
Jenis Kel & Perempuan & 30 & 83.3 \\
& Laki-laki & 6 & 16.7 \\
\multirow{5}{*}{ Pendidikan } & SD & 11 & 30.6 \\
& SMP & 14 & 38.9 \\
& SMA & 9 & 25.0 \\
\hline
\end{tabular}

Tabel 1 menunjukkan gambaran demografi subyek penelitian, berdasarkan kelompok umur responden terbanyak pada rentang usia dibawah 75 tahun sebanyak 24 orang $(66.7 \%)$, jenis kelamin didominasi oleh perempuan sebanyak 30 orang $(83.3 \%)$, dan pendidikan terbanyak SMP terdapat 14 orang $(38.9 \%)$.

\section{Uji Normalitas Data}

Untuk menentukan uji statistik yang akan digunakan terlebih dahulu dilakukan uji normalitas data hasil test sebelum dan sesudah intervensi. Uji normalitas menggunakan Uji Shapiro-Wilk test, hasilnya tertea pada tabel 2

Tabel 2. Hasil Normalitas Data Skor MMSE sebelum dan sesudah intervensi

\begin{tabular}{lc}
\hline Kelompok & $\begin{array}{c}\text { p Uji Normalitas } \\
\text { (Shapiro-Wilk Test) }\end{array}$ \\
\hline Pre test MMSE & 0.416 \\
Post test MMSE & 0.472 \\
\hline
\end{tabular}

Hasil dari uji normalitas data (Shapiro-Wilk test) sebelum dan sesudah intervensi memiliki nilai $\mathrm{p}>0.05$, yang berarti data skor MMSE sebelum dan sesudah intervensi berdistribusi normal

Pengujian Skor MMSE sebelum dan sesudah dilakukan training kognitif

Oleh karena hasil uji normalitas data baik pada kelompok sebelum maupun sesudah intervensi berdistribusi normal, maka untuk mengetahui perbedaan rerata kemampuan kognitif menggunakan uji parametrik dengan paired sample t-test (uji $\mathrm{t}$ sampel berpasangan). Hasil uji sampel berpasangan tertera pada tabel 4.3

Tabel 3. Uji Hipotesis Peningkatan Skor MMSE

\begin{tabular}{lccccc}
\hline Kelompok & $\mathrm{n}$ & Rerata & $\mathrm{SB}$ & \multicolumn{2}{c}{ Uji paired sample t-test } \\
& & & & $\mathrm{t}$ & $\mathrm{p}$ \\
\hline Sebelum & 36 & 21.53 & 2.667 & -9.555 & 0.001 \\
Sesudah & 36 & 23.17 & 3.085 & &
\end{tabular}

Tabel 3 menunjukkan beda rerata skor MMSE antara sebelum dan sesudah intervensi yang dilakukan uji paired sample t-test dengan hasil $\mathrm{p}=0.001$ $(<0.05)$. Hasil nilai tersebut mempunyai arti bahwa ada perbedaan rerata skor MMSE secara bermakna antara sebelum dan sesudah intervensi training kognitif. Apabila dikaitkan dengan hipotesis penelitian berarti ada pengaruh training kognitif terhadap kemampuan kognitif antara sebelum dan sesudah intervensi.

\section{KESIMPULAN DAN SARAN}

Berdasarkan hasil analisis dan uji statistik terhadap hasil intervensi training kognitif dengan metode yang telah direncanakan, dapat disimpulkan bahwa :

1. Terdapat pengaruh training kognitif terhadap kemampuan kognitif lansia di Desa Sobokerto Kecamatan Ngemplak Kabupaten Boyolali.

2. Berdasarkan distribusi umur lansia di Desa Sobokerto Kecamatan Ngemplak Kabupaten Boyolali didominasi pada umur $<75$ tahun.

3. Sebagian besar lansia di Desa Sobokerto Kecamatan Ngemplak Kabupaten Boyolali berjenis kelamin perempuan 
4. Tingkat pendidikan lansia di Desa Sobokerto Kecamatan Ngemplak Kabupaten Boyolali terbanyak pada tingkat SMP.

Berdasarkan temuan dan kajian pada penelitian ini beberapa saran yang diajukan :

1. Perlu kajian lebih mendalam dengan menilai masing-masing sub item indikator penilaian MMSE untuk menyelidiki aspek sub kognitif yang mana yang dapat diperbaiki dengan training kognitif.

2. Okupasi terapis dapat memberikan pelayanan terapi yang holistik terhadap lansia termasuk pendekatan kognitif untuk meningkatkan kemandirian dan kualitas hidup lansia.

\section{DAFTAR RUJUKAN}

Bustillo J, Lauriello J, Horan W, Keith S. 2001.The psychosocial treatment of schizophrenia: an update. Am J Psychiatry.;158:163-175.

Dorland, W.A.N. 2002. Kamus Kedokteran Dorland. Edisi 29. Jakarta: Penerbit Buku Kedokteran EGC

Green MF. 2009. New possibilities in cognition enhancement for schizophrenia. American Journal of Psychiatry.;166:749-752

Kemenkes RI. (2013a). Pedoman pembinaan kesehatan usia lanjut bagi petugas kesehatan I, kebijaksanaan program. Departemen Kesehatan RI.

Kuntjoro, Z.S. 2002. Masalah kesehatan jiwa lansia. Diakses 4 Desember 2010 dari: http://www.epsikologi.com/epsi/la njutuisa_detail.asp?id=182-17k-

Velligan DI, Mahurin RK, True JE, Lefton RS, \& Flores CV. 1996.
Preliminary evaluation of cognitive adaptation training to compensate for cognitive deficit in schizophrenia. American Psychiatric Association;47: 415417.

Velligan DI, Diamond PM, Maples NJ, et al. 2008. Comparing the efficacy of interventions that use environmental

supports to improve outcomes in patients with schizophrenia. Schizophr Res.;102:3212-3319. 